\title{
LONGITUDINAL STUDY OF LYME BORRELIOSIS IN A HIGH RISK POPULATION IN SWITZERLAND
}

\author{
ZHIOUA E..***, GERN L.*, AESCHLIMANN A.*, SAUVAIN M.J.***, VAN DER LINDEN S.**** \& FAHRER H.*****
}

\section{Summary :}

Orienteers from all parts of Switzerland $(n=416)$ were included in a longitudinal study for Lyme borreliosis. In spring 1986, the seroprevalence was $28.1 \%$. At the beginning of the study, $84.3 \%$ of orienteers reported a history of tick bite, and $3.8 \%$ reported a past history of Lyme borreliosis. During the first (spring 1986-autumn 1986), second (autumn 1986-spring 1987) and third (spring 1987-autumn 1987) period, rates of seroconversion were $0.6 \%, 2.7 \%$ and $2.1 \%$ respectively. During the first and second period, clinical incidence were $1.0 \%$ and $0.25 \%$ respectively. No active Lyme borreliosis was detected during the third period. Among orienteers who seroconverted during the study In $=|6|$, only two developed clinical symptoms. Hence, Borrelia burgdorferi infection is often asymptomatic.

KEY WORDS : Borrelia burgdorferi, Ixodes ricinus, orienteers, seroprevalence seroconversion, clinical incidence.
Résumé : ÉTUdE PROSPECTIVE DE LA BORRÉLIOSE DE LYME CHEZ UNE POPULATION SUISSE A HAUT RISQUE

Des coureurs d'orientation venant de loules les régions de Suisse In $=416$ l ont participé à une étude prospective de la borréliose de Lyme. Au printemps 1986, la séroprévalence était de 28,1\%. Au début de l'étude, $84,3 \%$ des coureurs d'orientation ont signalé avoir été piqués par des tiques. Durant la première période (printemps 1986-automne 1986), la deuxième lautomne 1986-printemps 1987) ef la troisieme (printemps 1987-automne 1987), les taux de séroconversion ont été respectivement de $0,6 \%, 2,7 \%$, et $2,1 \%$. Lors des première el deuxième périodes l'incidence clinique a éré respectivement égale à $1,0 \%$ et $0,25 \%$. Aucun cas clinique n'a été observé durant la troisième période. Parmi les coureurs ayant présenté une séroconversion durant cette étude $(n=16)$, deux seulement ont développé des symptômes cliniques. II semble donc que l'infection à Borrelia burgdorferi soit souvent asymptomatique.

MOTS CLÉS : Borrelia burgdorferi, lxodes ricinus, coureurs d'orientation seroprévalence, seroconversion, incidence clinique.

lato was described (Assous et al., 1993; van Dam et al., 1993; Balmelli \& Piffaretti, 1995). The natural biotope of I. ricinus is the forest (Aeschlimann, 1972). Therefore, outdoor activity for work or for leisure is considered to be a major risk factor for Lyme borreliosis. In Europe as in the USA, several cross-sectional studies in high risk populations showed a high seroprevalence and low clinical prevalence (Fahrer et al., 1988; Gern et al., 1989; Nadal et al., 1989; Goldstein et al., 1990; Zhioua et al., 1997). Longitudinal studies of high risk population showed a high rate of seroconversion and a low clinical incidence (Fahrer et al., 1991; Kuiper et al., 1993; Rath et al., 1996; Schwartz et al., 1994). It is unknown whether or not asymptomatic $B$. burgdorferi infection could later develop into an active Lyme borreliosis. In order to answer this question, long-term prospective studies are required. However, to date, few follow-up studies of relatively long duration concerning high risk populations have been performed in Europe.

Six months follow-up study of Lyme borreliosis among Swiss orienteers, a high risk population was performed (Fahrer et al., 1991). In this paper, we assess the incidence of symptomatic and asymptomatic infection with B. burgdorferi among orienteers during a two-year study. 


\section{MATERIALS AND METHODS}

\section{STUDY GROUP}

Orienteers run competitively using map and compass in order to localize certain points in the forest. They were asked for blood samples and to complete a questionnaire about tick exposure and possible Lyme borreliosis in spring 1986, autumn 1986, spring 1987, and autumn 1987. Three period were designed in this study. Periods I, II and III corresponded respectively to the six months from spring 1986 to autumn 1986, autumn 1986 to spring 1987 and spring 1987 to autumn 1987. During each blood sampling, a poster with information on the clinical spectrum of Lyme borreliosis and on the vector was shown. If the answers on the questionnaire suggested possible Lyme borreliosis (e.g., redness of the skin or neurologic or joint symptoms), further information was obtained by telephone interview. Lyme borreliosis was considered as definite if we received the confirmation from a physician, and probable if the description of the symptoms strongly suggested Lyme borreliosis, but a physician had not been consulted.

\section{CONTROL GROUPS}

Serum samples were obtained from two control groups. Group A consisted of 51 healthy blood donors who live at high altitudes $(>1000 \mathrm{~m})$, where $I$. ricinus is rare at 1000-1500 m (Aeschlimann, 1972). No demographic data were available concerning group A. Group B consisted of 50 healthy individuals (18 male and 32 female) that were not engaged in orienteering. The mean age in the group $\mathrm{B}$ was $38.1 \pm 15.8$ years.

\section{SEROLOGICAL ASSAY}

Lyme borreliosis serology was performed by ELISA as previously described by Fahrer et al (1991). The ELISA sonicate antigen (strain B31) was prepared according to the method described by Russell et al. (1984). In each assay, one pooled negative control serum and a diluted positive test serum (six times) from 1:300 to 1:9600 were included. The obtained curve was used as reference for study sera. The optical density (OD) of each sample was marked on this line and the result was expressed as the logarithm of the diluted (log dil) positive test serum. Low log dil values correspond with lesser dilution of the positive test serum represent high anti$B$. burgdorferi antibody levels. A log dil of $\leq 3.74$ (corresponding to 2 SD below the mean dilution of 51 sera of people living at high altitude where I. ricinus is supposed to be absent) is the cutoff point for IgG antiB. burgdorferi antibodies (Fahrer et al., 1991). At this cut-off level, the specificity of the test is $96 \%$ if other spirochetes such as leptospires and treponemes were excluded. The sensitivity of the test varied from $26 \%$ to $100 \%$ depending on clinical manifestations in cases of definite Lyme borreliosis (Fahrer et al., 1991).

Seroconversion was defined as a shift from negative to positive with a decrease of at least 0.4 on the log dil (Fahrer et al., 1991). Seroreversion is considered as a shift from positive to negative

\section{STATISTICAL ANALYSIS}

A contingency table was used to compare differences between groups.

\section{RESULTS}

F Tour hundred and sixteen orienteers contributed the four different blood samples types. Among them, 218 (52.4\%) were male and 198 female. The age varied from 21 to 75 years with a mean of $54.0(\mathrm{SD}=13.7)$.

Seroprevalence observed in the control groups $\mathrm{A}$ and B were $3.9 \%(2 / 51)$, and $6 \%(3 / 50)$, respectively. Seroprevalence observed in orienteers in spring (1986), autumn (1986), spring (1987), and autumn (1987) were $28.1 \%(117), 29.8 \%(124), 30.3 \%$ (126), and $29.8 \%$ (124), respectively. Seroprevalence did not differ from spring 1986 to autumn $1987(\chi 2=0.54, P>0.05)$. The percentages of orienteers with seroconversion during the three study period were respectively $0.6 \%(2 / 299)$, $2.7 \%(8 / 292)$, and $2 \%(6 / 290)$; no significant difference was observed among these rates $(\chi 2=3.71, P>$ 0.05 ). The percentages of orienteers with seroreversion during the three study periods were $6.8 \%(8 / 117)$, $13.7 \%(17 / 124)$ and $15.1 \%(19 / 126)$, respectively; no significant difference was observed among these rates $(\chi 2=4.43, P>0.05)$.

At the first blood sample (spring 1986), $84.3 \%$ (351/416) reported a history of tick bite. The percentage of orienteers who reported a tick bite during period I, II, and III were $55.7 \%$ (232), $30.0 \%$ (125), and $55.7 \%$ (232), respectively. The percentage of orienteers who reported a tick bite differed significantly among the three periods $(\chi 2=73.62, P<0.05)$. The percentage of orienteers who reported tick bite during the second period was lower than the rates reported in the two other periods. During the three study periods, $20.4 \%(85 / 416)$ of the orienteers reported a tick bite, and only $1.9 \%(8 / 416)$ reported no tick bite. Hence, one fifth of this population was repeatedly bitten by ticks. Of these 85 orienteers who reported a tick bite during the three study periods, four $(4.7 \%)$ had developed Lyme borreliosis in the past. None of the 85 orienteers developed clinical manifestations during the two-year investigation. Their correspondent seroprevalence observed during the four blood 


\begin{tabular}{|c|c|c|c|c|c|c|}
\hline \multirow{2}{*}{$\begin{array}{l}\text { Patient } \\
\text { no. }\end{array}$} & \multirow{2}{*}{$\begin{array}{c}\text { Clinical } \\
\text { manifestations }\end{array}$} & \multirow{2}{*}{$\begin{array}{c}\text { Mo/Ye } \\
\text { of disease }\end{array}$} & \multicolumn{4}{|c|}{ IgG ELISA } \\
\hline & & & S86 & A86 & 587 & A87 \\
\hline 1 & EM & 8/86 & 4.27 & 4.06 & 3.88 & 4.04 \\
\hline 2 & EM & $10 / 86$ & 3.14 & 3.22 & 3.09 & 2.77 \\
\hline 3 & APP & $4 / 86$ & 3.59 & 3.88 & 3.78 & 4.03 \\
\hline 4 & Bell's palsy & $6 / 86$ & 3.99 & $2.62^{*}$ & 2.73 & 2.98 \\
\hline 5 & EM & 86 & 4.10 & 4.15 & $3.02^{*}$ & 2.61 \\
\hline
\end{tabular}

" seroconversion; positive if $\operatorname{lgG} \leq 3.74$; $\mathrm{s}$ : spring; A: autumn; Mo: month; Ye: year; EM: erythema migrans; APP: atrophoderma Pierini-Pasini.

Table 1. - Clinical and serological findings of patients with active Lyme borreliosis during the two-year survey.

samples were $32.9 \%(28), 32.9 \%(28), 32.9 \%(28)$ and $35.3 \%(30)$, respectively.

On the basis of the questionnaire, 16 orienteers reported a history of Lyme borreliosis (eight definite and eight probable). Therefore, the clinical prevalence was $3.8 \%(16 / 416)$. In this group, the frequency of Erythema Migrans (EM) was $68.7 \%(11 / 16)$. Neurological and articular symptoms were less frequently observed $(37.5 \%=6 / 16)$

During period $\mathrm{I}$, the clinical incidence was $1.0 \%$ (4/400) (Table I, patient no. 1 to 4). During period II, only one EM was observed (Table I, patient no. 5); hence, the clinical incidence during this period was $0.25 \%(1 / 396)$. All clinical cases observed during the two-year study were definite. No clinical case was observed during period III. No significant difference was observed between these clinical incidence (Fisher exact test, $P=0.12$ ). The annual incidence (spring 1986-spring 1987) was $1.25 \%(5 / 400)$.

During the two year follow-up study, 16 orienteers showed seroconversion. Among them, only two developed clinical symptoms (Table I, patients no. 4 and 5). Patient no. 2 (Table I) who was seropositive in spring 1986 developed FM later in autumn 1986.

\section{DISCUSSION}

The percentage of orienteers with a history of a tick bite is high and varies significantly with season of tick activity. Therefore, orienteers are considered as a high risk population because of their high exposure to tick bites. A longitudinal study performed on a population at risk in Germany showed that $53.8 \%$ of forestry workers reported a history of tick bites at the beginning of the study; six months later, $32.7 \%$ of participants reported a tick bite during this interval (Rath et al. 1996). Similar findings were reported in Sweden, where more than $30 \%$ of participants reported a history of tick a bite each year (Gustafson et al., 1992).
In Switzerland, the infection rate of $I$. ricinus with B. burgdorferi varies from 5 to $35 \%$ (Aeschlimann et al., 1986). Due to the high frequency of orienteers with a tick bite history, a high seroprevalence among this population was expected. Seroprevalence and seroconversion observed in orienteers remained stable over a two-year follow-up period. A comparable study on a high risk population from Sweden showed that the seroprevalence and the seroconversion remained stable over a two-year follow-up period (Gustafson et al., 1992). Seroprevalence observed in 1987, 1988, and 1989 were $25.7 \%, 26.4 \%$, and $29.2 \%$, respectively (Gustafson et al., 1992). Seroconversion observed in first year and the second year were $4.6 \%$, and $2.9 \%$, respectively (Gustafson et al., 1992). However, in the USA, one longitudinal study on outdoor workers (New Jersey) showed that seroprevalence and seroconversion fluctuated significantly with time (Schwartz et al., 1994). Seroprevalence reached a peak of $18.7 \%$ in 1990 before decreasing to $4.4 \%$ in 1991 (Schwartz et al., 1994). Seroconversion observed in 1989, 1990, and 1991 were $6.8 \%, 16.7 \%$, and $0.6 \%$, respectively (Schwartz et al., 1994). The significant decrease in seroprevalence and seroconversion observed in outdoor workers was attributed partly to the probable benefit of ongoing educational programs and systematic treatment of all seropositives (Schwartz et al., 1994).

The present study showed that $12.5 \%(2 / 16)$ of orienteers with seroconversion, developed clinical symptoms. Similar findings were observed in Sweden; only $9.1 \%(2 / 22)$ of individuals with seroconversion showed clinical manifestations (Gustafson et al., 1992). In the Netherlands, $5 \%$ of forestry workers showed asymptomatic seroconversion (Kuiper et al. 1993). In Germany, seroconversion was observed among $7.2 \%$ of forestry workers; none had developed clinical symptoms (Rath et al. 1996). The majority of seroconversion observed in New Jersey were asymptomatic (Schwartz et al. 1994). Therefore, B. burgdorferi infection is often asymptomatic.

The annual clinical incidence observed among orienteers in Switzerland $(1.25 \%)$ was within the range reported from other European countries: $0 \%$ in Germany (Rath et al. 1996); $0 \%$ in the Netherlands (Kuiper et al. 1993), and $2.9 \%$ in Sweden (Gustafson et al. 1992). This figure is also similar to the annual incidence reported in two studies in the USA which ranged from o to $3.3 \%$ (Hanrahan et al., 1984; Steere et al., 1986).

During the two-year survey, no clinical symptoms were observed among the majority of orienteers with seroconversion and among almost all those seropositive at the time of the first blood sample without a history of Lyme borreliosis. Borrelia burgdorferi infection is frequent among orienteers, but seems to take a benign course. 


\section{ACKNOWLEDGEMENTS}

T The authors thank the Swiss National Science Foundation (Grant no. 3.892-0.86) and the Federal Commission for Foreign Scholarship. We are grateful to Drs. H. Ginsberg, R. LeBrun, B.S. Schwartz, $\mathrm{U}$. Whitworth Jr. and M. Nicholson for reviewing the manuscript. This work constitutes part of the Ph.D. thesis of Elyes Zhioua. This is contribution 3421 of the College of Resource Development, University of Rhode Island.

\section{REFERENCES}

AEsChlimann A. Ixodes ricinus L., Essai préliminaire de synthèse sur la biologie de cette espèce en Suisse. Acta tropica, 1972, 29, 321-340.

Aeschlimann A., Chamot E., Gigon F., Jeanneret J.P., KesSELER D. \& WALTHER C. Borrelia bungdorferi in Switzerland. Zentralblatt für Bakteriologie, 1986, A 263, 450-458.

Assous M.V., Postic D., Paul G., Névot P. \& Baranton G. Western blot analysis of sera from Lyme borreliosis patients according to the genomic species of the Borrelia strains used as antigens. European Joumal of Clinical Microbiology \& Infectious Diseases, 1993, 12, 261 268.

Balmelli T. \& Piffarett J.C. Association between different clinical manifestations of Lyme disease and different species of Borrelia burgdorferi sensu lato. Research Microbiology, $1995,146,329-340$

Fahrer H., Sauvain M.J., Van der Linden S., Zhiola E., Gern L. \& Afschlimann, A. Prävalenz der Lyme-Borreliose in einer schweizerischen Risikopopulation. Schweizerische Mediziniscbe Wochenscbrift, 1988, 118, 65-69.

Fahrer H., Van der linden S., Sauvain M.J., Gern L., Zhioua E. \& Afschlimann A. The prevalence and incidence of clinical and asymptomatic Lyme Borreliosis in a population at risk. Journal of Infectious Diseases, 1991, 163, 305-310.

Ferté H., Postic D., Baranton G., Ulmer Ph., Chippaux, C. \& LÉGER N. Premier isolement en France (Marne) de Borrelia afzelii à partir d'Ixodes ricinus. Bulletin de la Société de Patbologie Exotique, 1994, 87, 226-227.

Gern L., Frossard E., Walter A. \& Aeschlimann A. Presence of antibodies against Borrelia burgdorferi in a population of the Swiss Plateau. Zentralblatt für Bakteriologie, 1989, Supplement 18, 321-328.

Goldstein M.D., Schwartz B.S., Friedmann C., Maccarillo B., Borial M. \& Tuccillo R. Lyme disease in New Jersey: A statewide survey of seroprevalence and tick exposure. American Journal of Public Health, 1990, 80, 1225-1229.

Gustafson R., Svenungsson B., Forsgren M., Gari)ulf A. \& Granström M. Two-year survey of the incidence of Lyme borreliosis and tick-borne encephalitis in a high-risk population in Sweden. European Joumal of Clinical Microbio$\log y$ E Infectious Diseases, 1992, 11, 894-900.
Hanrahan J.P., Benach J.L., Coleman J.L., Bosler, E.M., Morse D.L., Camiron D.J., Edelman R. \& Kaslow R, A. Incidence and cumulative frequency of endemic Lyme disease in a community. Journal of Infectious Diseases, 1984, 150, 489-496.

Kuiper H., Van Dam A.P., Moll van Charante A.W., Nauta N.P. \& DANKERT J. One year follow-up study to assess the prevalence and incidence of Lyme borreliosis among Dutch forestry workers. European Journal of Clinical Microbiology E Infectious Diseases, 1993, 12, 413-418.

Nadal D., Wunderli W., Briner H. \& Hansen K. Prevalence of antibodies to Borrelia burgdorferi in forestry workers and blood donors from the same region in Switzerland. European Journal of Clinical Microbiology \& Infectious Diseases, 1989, 8, 992-995.

Péter O., Bretz A.G. \& BeE D. Occurence of different genospecies of Borrelia burgdorferi sensu lato in ixodid ticks of Valais, Switzerland. European Joumal of Epidemiology, $1995,11,463-467$

Postic D., Korenblirg E., Gorelova N., Kovalevski Y.V., BeiLENGer E. \& Baranton G. Borrelia burgdorferi sensu lato in Russia and neighbouring countries: high incidence of mixed isolates. Research Microbiology', 1997, 148, 691-702.

Rath P.M., Ibershoff B., Mohnhaup A., Albig J, Eljaschewitsch B., Jürgens D., Horibach I. \& Fihrenbach F.J. Seroprevalence of Lyme borreliosis in forestry workers from Brandenburg, Germany. European Journal of Clinical Microbiology \& Infectious Diseases, 1996, 15, 372-377.

Russell H., Sampson J.S., Schmid G.P., Wilkinson H.W. \& PliKAYTIS B. Enzyme-linked immunosorbent assay and indirect immunofluorescence assay for Lyme disease. Joumal of Infectious Diseases, 1984, 149, 465-470.

SChwarTz B.S., Goldstein M.D. \& ClilLDs J.E. Longitudinal study of Borrelia burgdorferi infection in New Jersey outdoors workers, 1988-1991. American Journal of Epidemiology, 1994, 139, 504-512.

Steere, A.G. Lyme disease. Neu' England Jon mal of Medicine, $1989,321,586-596$

Steere A.G., Taylor E., Wilson M.L., Livine J.F., \& Spiflman A. Longitudinal assessment of the clinical and epidemiological features of Lyme disease in a defined population. Joumal of Infectious Diseases, 1986, 154, 295-300.

van Dam A.J., Kulper H., Vos K., Widjojkusumo A., DE JoNGH B.M., Spanjaari L., Ramselaar A.C.P., Kramer D.M. \& DanKERT J. Different genospecies of Borrelia burgdorferi are associated with distinct clinical manifestations of Lyme disease. Clinical and Infectious Diseases, 1993, 17, 708717.

Zhioua E., Postic D., Rodhain F. \& Perez-Eid C. Infection of Ixodes ricinus (Acari: Ixodidae) by Borrelia burgdorferi in lle de France. Joumal of Medical Entomology, 1996, 33, 694-697.

Zhioua E., Rodhain F., Binet Ph. \& Perez-Eid C. Prevalence of antibodies to Borrelia bungdorferi in forestry workers of Ile de France, France. European Joumal of Epidemio$\log \mathcal{y}, 1997,13,959-962$.

Reçu le 17 septembre 1997 Accepté 10 septembre 1998 